\title{
COGNITIVE NEUROSCIENCE TOOLS IN ECONOMIC EXPERIMENTS INVESTIGATING THE DECISION MAKING PROCESS
}

\author{
Anna Borawska, Ph.D., Eng. \\ University of Szczecin \\ Faculty of Economics and Management \\ Institute of IT in Management \\ Mickiewicza 64, 71-101 Szczecin, Poland \\ e-mail: anborawska@gmail.com
}

Received 4 January 2017, Accepted 21 March 2017

\begin{abstract}
Experimental economics utilises a lot of different techniques to support its research. Applying computers and IT has already become common. As a novel approach the use of cognitive neuroscience tools is now being considered. Investigating the neurophysiological signals of experiment participants can give researchers a deeper insight into a decision making process. The aim of the article is to show how neuroscience techniques can contribute to economic experiments, especially those concerning decision making. The overview and presentation of the possibilities of such tools is shown regarding different stages of the decision making process and related experimental studies. The proposed analysis could allow for the better design of economic experiments conducted with the use of the most up-to date technology available.
\end{abstract}

Keywords: cognitive neuroscience, experimental economics, decision making process

JEL classification: C99, D87 


\section{Introduction}

Cognitive neuroscience is a new and rapidly developing field of multidisciplinary research. It brings together many different scientific domains, chiefly psychology and neurobiology, but also philosophy, linguistics and many other sciences that incorporate the study of the mind in their programs. Despite the fact that cognitive neuroscience has emerged as a discipline only over the last two-three decades, due to advancement in technology, especially in neuroimaging and the computational capabilities of processing recorded signals, it is widely used in many different applications. Experimental economics is not an exception to this trend.

In economics research four major areas most often make use of experiments. These are studies concerning: individual decision making and eliciting preferences, game theory, social dilemmas and the functioning of the market and its regulations. These are the core topics when it comes to experiments with the use of cognitive neuroscience tools as well. However, due to the specific way of recording the data and the equipment that is needed, the performed research is limited mostly to the issues of individual human beings. As a result, the dominating trends of neuroscientific experiments in economics are (Kopczewski, Malawski, 2007; Loewenstein, Rick, Cohen, 2008):

- individual decision making,

- intertemporal choice,

- risk attitudes,

- eliciting individual preferences,

- social dilemmas.

The aim of the article is to show how neuroscience techniques can contribute to economic experiments, especially those concerning decision making. To achieve this goal a short description of different neuroscience techniques is presented and their possible contribution to economic experiments is emphasised. Then, the paper focuses on the decision making process and its stages to set the background for the final section that discusses contemporary and future applications of neuroscience techniques in economic experiments to investigate certain phases of such a process.

The research was conducted with the use of literature review method, according to a procedure consisting of five main stages:

- selecting the research question,

- searching the literature in scientific databases,

- gathering and selecting the most relevant literature, 
- literature analysis,

- summarizing and synthesizing.

The review focused mainly on scientific literature concerning cognitive neuroscience research, the decision making process, and economic experiments. When selecting studies for the review, the Internet resources were searched for with the use of such keywords as: cognitive neuroscience techniques, decision making process, decision biases, intuition, cognitive load, experiment, and economics. In the scope of neuroscientific research and experimental economics, only the newest contributions were chosen (published in the past 10 years). The decision making process was presented from the point of view of some canonical publications in this field.

\section{Cognitive Neuroscience Tools in Experimental Economics}

The potential of cognitive neuroscience is primarily due to the development of brain activity measurement technologies (such as functional magnetic resonance imaging, fMRI) and to the adaptation of older technologies (including eye-tracking or electroencephalography) for new applications (Camerer, 2007). The commonly used techniques of cognitive neuroscience can be divided into four main groups (Zaleśkiewicz, 2008; Shiv et al., 2005):

- neuroimaging of the brain,

- neurophysiological techniques,

- examination of individual nerve cells,

- neuropsychological techniques (the study of neurological patients with brain damage).

In studies that are unrelated to medicine mainly neuroimaging and neurophysiological techniques are used, so they will be described in more detail in the following part of the paper.

Neuroimaging is associated with a group of research methods used to studying the structure and function of the brain. Among them there are electro- and magneto-physiological techniques, exploring the electrical and magnetic activity of neurons, and tomographic methods in which inferences about neuronal activity are made indirectly (Jaśkowski, 2009). Generally, in the area of economic sciences the most applicable methods are: electroencephalography (EEG) and functional magnetic resonance imaging (fMRI).

EEG is focused on the measurement of brain electrical activity recorded by electrodes placed on the scalp at specific locations (Purves et al., 2013). Because of its very good temporal resolution, this method is usually used to study changes in brain activity in time and to analyse reactions to external stimuli (Zaleśkiewicz, 2008). Electroencephalography is not specific enough to determine exactly which areas of the brain are activated during performing certain 
tasks. In such applications, fMRI is much better suited. With its help, you can tell how much oxygen is delivered to specific parts of the brain and deduce their activity. This data contributes to the understanding of the biological basis underlying a performed task (Purves et al., 2012).

Functional magnetic resonance imaging has very good spatial resolution but conducting an examination with the use of this method can be cumbersome. In cases where decent temporal and spatial resolution is needed, the experiment should be as comfortable for a participant as possible, there is another one, quite novel imaging method, i.e. functional near-infrared spectroscopy (fNIRS) - a non-invasive technique for the optical estimation of cortical activity. It relies on the low optical absorption of the biological tissue of the infrared radiation in the 650-1000 nm wavelength window (Ferrari, Quaresima, 2012). That represents a powerful tool to non-invasively study task-evoked brain activity and it gains more and more popularity in recent research.

Neurophysiological techniques are based on the correlation of brain functions with physiological sensations (Zaleśkiewicz, 2008). The most frequently used (especially in experiments on the effect of emotions on the actions and cognitive functions of respondents) are the measurements of galvanic skin-response (GSR), heart rate (HR) and eye-tracking (ET). The reason for their popularity is relatively simple, in comparison to neuroimaging, registration and the interpretation of signals.

The GSR measurement is based on detecting electrical changes in the skin (Dawson, Schell, Filion, 2007) and it is mostly performed on the skin of the hand (fingers). Heart rate measurement is performed on the wrist of the left hand or on the chest - the frequency of heart beats per minute is recorded (Dulleck, Schaffner, Torgler, 2014).

Eye-tracking, on the other hand, is an effective tool for experimental research because of its abilities to detect the eye position, gaze direction, sequence of eye movement and visual adaptation during cognitive activities. With appropriate software, ET provides both a quantitative and qualitative analysis of the gaze, which is very useful in understanding choice and decision making behaviour (Popa et al., 2015).

The utility of cognitive neuroscience techniques to economics is threefold (Farb, 2013). First, they may offer greater fidelity than measures relying upon self-report. In an experimental context, demand characteristics and participants' knowledge may sometimes mask their true response patterns. By measuring the neurophysiological activity of the subjects, researchers hope to bypass such problems as a lack of insight into the true mechanisms of choice (Ariely, Berns, 2010). Secondly, there are substantial information processes in the brain that determine economic decision making that are not easily observed through behavioural research methods. 
This fact is demonstrated by experiments that use transmagnetic stimulation to modulate the brain (Fehr, Rangel, 2011). These studies confirm a causal relationship between brain activity and economic choice, above and beyond environmental factors. The third element is that cognitive neuroscience techniques have the potential to discover new and important factors that contribute to economic theory. They may reveal fundamental principles of decision making that may not have been considered relevant in traditional economic research. For example, such techniques may help to explain how decision making changes under particular contexts, such as the physical environment, mood, or a person's cultural background. From a scientific perspective, the modelling of how these different contextual factors influence decision making is important for making realistic predictions of behaviour.

Investigating decision making with neurophysiological techniques is therefore a very interesting research approach that this article aims to explore. Before exploring the applicability of cognitive neuroscience in decision making experiments, some base information about the decision process stages will be presented.

\section{The Decision Making Process and its Stages}

Generally speaking, a decision-making process (simply called a decision process) begins with the awareness of a decision problem, and ends up with a final solution among finite or infinite alternatives. A general decision-making process proposed by Simon $(1960,1977)$ involves three main phases: Intelligence, Design, and Choice. Other authors, like Mintzberg, Raisinghani and Theoret (1976), propose slightly different terms to name these stages: Identification, Development and Selection. Despite the differences in naming convention, these three following stages of the decision making process consist of very similar activities. Intelligence (identification) activity involves gathering and processing information, providing cues for recognizing potential decision needs or opportunities (diagnosis), and for formulating alternatives. Design (development) activity involves identifying alternative courses of action in order to determine likely outcomes and whether these outcomes will satisfy the needs or goals associated with the decision. In the choice (selection) activity, decision-makers make judgements and choose among the previously identified alternatives.

Several other authors proposed alternatives to Simon's phases (i.e. Glueck,1976; Hofer, Schendel, 1978; Mazzolini, 1981; Schwenk, 1984; Gore, Murray, Richardson, 1992; Van de Ven, 1992; Lu, Zhang, Ruan, Wu 2007). An analysis of their approaches shows, however, that each contribution consists of disaggregating or aggregating some phases identified in former 
contributions. However, the three main phases proposed by Simon are always present (although sometimes with slightly different names), and all existent models are in many respects similar (Fredrickson, 1985; Gore et al., 1992; Schwenk, 1984).

The most typical steps and the course of the decision making process are shown in Figure 1.

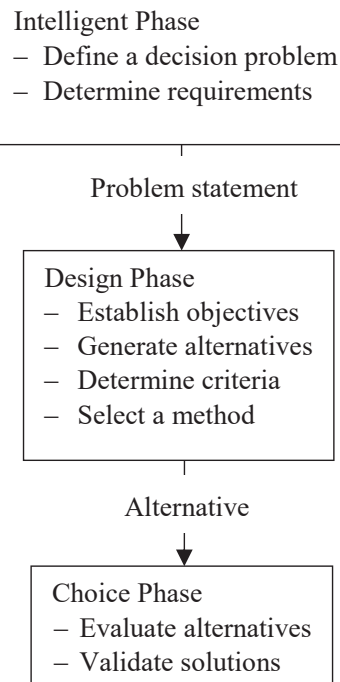

Choice Phase

- Evaluate alternatives

- Validate solutions

Figure 1. Phases of the decision making process according to Simon $(1960,1977)$

Source: Simon $(1960,1977)$

Some sources incorporate into this process a fourth phase, which is the implementation of the choice (Niu, Lu, Zhang, 2009) but from the point of view that is represented in this paper the realization of the decision is not strictly a mental task, so it is not the area of interest for cognitive neuroscience techniques. The rest of the article will be therefore focused on three stages only: Intelligent, Design and Choice.

\section{Applicability of Cognitive Neuroscience in Decision Making Experiments}

As it has already been mentioned before, economic experiments concerning decision making focus primarily on individual decision making (especially under risk and uncertainty), intertemporal choice and social decision making. The great share of research conducted in this scope is focused mainly on the (ir)rationality of decision makers. They challenge in various ways a very popular economic theory of expected utility (EU). Many independent economic 
experiments have already shown that people do not behave according to the predicted model. Some comprehensive overviews of the findings that were obtained in this scope are available in the literature (e.g. Harrison, 1994; Kagel, Roth, 1997; Yagub, Saz, Hussain, 2009).

Experimental economics has an insight into some deviations from the EU theory on the basis of behavioural evidence given by the participants of research but only with cognitive neuroscience would it be possible to find some explanations why people do not behave as rationally as they are supposed to. The existing decision-making literature in general, and the cognitive neuroscience literature in particular, has focused especially on the last phase of the decision making process: evaluation and choice (Fellows, 2004) and this aspect has been the most intensively studied to date. The other phases could be, however, also quite interesting for investigation. The overview of the possible applications of cognitive neuroscience tools in different phases of the decision making process are presented in Table 1.

Table 1. Research possibilities with the use of cognitive neuroscience techniques in the scope of different stages of the decision making process

\begin{tabular}{|c|c|c|c|c|}
\hline $\begin{array}{l}\text { Research pos- } \\
\text { sibility }\end{array}$ & $\begin{array}{l}\text { Decision making } \\
\text { process phases }\end{array}$ & $\begin{array}{l}\text { Useful cognitive } \\
\text { neuroscience } \\
\text { techniques }\end{array}$ & $\begin{array}{l}\text { Exemplary } \\
\text { research }\end{array}$ & Aim of research \\
\hline 1 & 2 & 3 & 4 & 5 \\
\hline \multirow[b]{2}{*}{$\begin{array}{l}\text { Decision biases } \\
\text { recognition }\end{array}$} & \multirow[b]{2}{*}{$\begin{array}{l}\text { Intelligent, De- } \\
\text { sign, Choice }\end{array}$} & \multirow[b]{2}{*}{ fMRI, EEG, fNIRS } & $\begin{array}{l}\text { De Martino, } \\
\text { Kumaran, } \\
\text { Seymour, } \\
\text { Dolan (2006) }\end{array}$ & $\begin{array}{l}\text { Authors investigated individual decision } \\
\text { making and the framing effect with the } \\
\text { use of functional magnetic resonance } \\
\text { imaging and a novel financial decision- } \\
\text { making task concerning the choice be- } \\
\text { tween two options in different contexts. }\end{array}$ \\
\hline & & & $\begin{array}{l}\text { Frydman, } \\
\text { Camerer } \\
(2016)\end{array}$ & $\begin{array}{l}\text { Authors use neural data collected from } \\
\text { an experimental asset market to measure } \\
\text { regret preferences while subjects trade } \\
\text { stocks. They have discovered that sub- } \\
\text { jects are unwilling to repurchase stocks } \\
\text { that have recently increased in price, } \\
\text { even though this is suboptimal in our } \\
\text { experiment. }\end{array}$ \\
\hline \multirow{2}{*}{$\begin{array}{l}\text { Strategic deci- } \\
\text { sion making }\end{array}$} & \multirow{2}{*}{ Design } & \multirow{2}{*}{ fMRI, EEG, fNIRS } & $\begin{array}{l}\text { Coricelli, } \\
\text { Nagel (2009) }\end{array}$ & $\begin{array}{l}\text { Authors used functional magnetic reso- } \\
\text { nance imaging (fMRI) to investigate the } \\
\text { cognitive processing underlying actual } \\
\text { choices in the experimental game, } \\
\text { in order to identify the neural substrates } \\
\text { of different levels of strategic thinking. }\end{array}$ \\
\hline & & & $\begin{array}{l}\text { Laureiro- } \\
\text {-Martinez, } \\
\text { Venkatraman, } \\
\text { Cappa, Zollo, } \\
\text { Brusoni } \\
(2015)\end{array}$ & $\begin{array}{l}\text { The article discusses the possibilities } \\
\text { and limitations of merging the cogni- } \\
\text { tive neuroscience and strategic decision } \\
\text { making research. }\end{array}$ \\
\hline
\end{tabular}




\begin{tabular}{|c|c|c|c|c|}
\hline 1 & 2 & 3 & 4 & 5 \\
\hline \multirow{2}{*}{$\begin{array}{l}\text { Detection of dif- } \\
\text { ferent emotional } \\
\text { and psycho- } \\
\text { physiological } \\
\text { states influence } \\
\text { on decision } \\
\text { making (e.g. } \\
\text { stress, anger) }\end{array}$} & \multirow[t]{2}{*}{ Choice } & \multirow[t]{2}{*}{ HR, GSR } & $\begin{array}{l}\text { Dulleck et al. } \\
\text { (2014) }\end{array}$ & $\begin{array}{l}\text { In the study cognitive neuroscience } \\
\text { technology was applied to measure the } \\
\text { influence of physiological reactions } \\
\text { (stress) of participants in an economic } \\
\text { experiment on their decision making. }\end{array}$ \\
\hline & & & $\begin{array}{l}\text { Kang, Camer- } \\
\text { er (2017) }\end{array}$ & $\begin{array}{l}\text { Authors study the influence of anxiety } \\
\text { on decisions concerning the purchasing } \\
\text { assets. }\end{array}$ \\
\hline \multirow{2}{*}{$\begin{array}{l}\text { The role of } \\
\text { intuition in deci- } \\
\text { sion making }\end{array}$} & \multirow{2}{*}{ Choice } & \multirow{2}{*}{ fMRI, EEG, fNIRS } & $\begin{array}{l}\text { Volz, von } \\
\text { Cramon } \\
(2006)\end{array}$ & $\begin{array}{l}\text { Authors used functional magnetic reso- } \\
\text { nance imaging to approach the nature } \\
\text { of intuitive processes and to discover } \\
\text { neural patterns indicating intuitive } \\
\text { judgements. }\end{array}$ \\
\hline & & & $\begin{array}{l}\text { Zander, Horr, } \\
\text { Bolte, Volz } \\
(2016)\end{array}$ & $\begin{array}{l}\text { The study addresses the issue of in- } \\
\text { tuitive decision making processes and } \\
\text { investigates the difference between } \\
\text { intuition-based and priming-based } \\
\text { decisions. }\end{array}$ \\
\hline \multirow[b]{2}{*}{$\begin{array}{l}\text { Cognitive over- } \\
\text { load detection }\end{array}$} & \multirow[b]{2}{*}{ Choice } & \multirow[b]{2}{*}{ ET, fMRI } & $\begin{array}{l}\text { Howard et al. } \\
(2015)\end{array}$ & $\begin{array}{l}\text { In the study functional magnetic reso- } \\
\text { nance imaging (fMRI) was used to iden- } \\
\text { tify and quantify the neural correlates } \\
\text { of the cognitive load level placed on the } \\
\text { participants of the experiment. }\end{array}$ \\
\hline & & & $\begin{array}{l}\text { Hahn, Lee, } \\
\text { Chae (2016) }\end{array}$ & $\begin{array}{l}\text { The study was concerned with using } \\
\text { rational and emotional stimuli and } \\
\text { analysing the changes of visual attention } \\
\text { responses with the aid of the eye-track- } \\
\text { ing method. With this method, authors } \\
\text { investigated respondent's cognitive load } \\
\text { and need-for-cognition. }\end{array}$ \\
\hline
\end{tabular}

Source: own elaboration.

Not all the possibilities mentioned in Table 1 have already been explored in decision making experiments with the use of cognitive neuroscience techniques. Their realization would be very interesting and could provide a deeper understanding of different aspects of the decision making process that cannot be studied with the use of traditional methods.

\section{Conclusions}

Cognitive neuroscience has just begun to provide data relevant to the brain-based understanding of human decision making. There is still a lot to discover in this field. More profound and deep knowledge and understanding of how the brain functions is needed to explain all the mysteries of human decision making. Experimental economics can derive a lot from neuroscience in designing and performing research. Neuroscientific tools supplement the experimentalist's toolbox in a significant way. Despite the various and obvious advantages, it 
has to be stated that a lot of interdisciplinary expertise is needed to use them in research. Another drawback is the cost connected with using the specialised equipment, especially when it comes to fMRI. Last but not least, the amount of neurophysiological data that is obtained during the average cognitive neuroscience experiment is enormous, thus demanding very sophisticated data analysis methods. All these obstacles, however taxing, can be overcome, and every scientist interested in experiments concerning the decision making process (and other economic domains as well) should consider applying cognitive neuroscience in their research.

\section{References}

Ariely, D., Berns G.S. (2010). Neuromarketing: the hope and hype of neuroimaging in business. Nature Reviews Neuroscience, 11 (4), 284-292.

Camerer, C.F. (2007). Neuroeconomics: Using neuroscience to make economic predictions. Economic Journal, 117 (519), C26-C42.

Coricelli G., Nagel, R. (2009). Neural correlates of depth of reasoning in medial prefrontal cortex. Proceedings of the National Academy of Sciences of the United States of America, 106 (23), 9163-9168.

Dawson, M.E., Schell, A.M., Filion, D.L. (2007). The Electrodermal System. In: J.T. Cacioppo, L.G. Tassinary, G. Berntson (eds.), Handbook of Psychophysiology. Cambridge University Press.

De Martino, B., Kumaran, D., Seymour, B., Dolan, R.J. (2006). Frames, biases, and rational decision-making in the human brain. Science, 313 (5787), 684-687.

Dulleck, U., Schaffner, M., Torgler, B. (2014). Heartbeat and economic decisions: observing mental stress among proposers and responders in the ultimatum bargaining game. PLoS ONE, 9 (9), e108218.

Farb, N.A.S. (2013). Can neuroimaging inform economic theories of decision making? Neuroscience and Neuroeconomics, 2, 1-10.

Fehr, E., Rangel, A. (2011). Neuroeconomic Foundations of Economic Choice - Recent Advances. Journal of Economic Perspectives, 25 (4), 3-30.

Fellows, L.K. (2004). The Cognitive Neuroscience of Human Decision Making: A Review and Conceptual Framework. Behavioral and Cognitive Neuroscience Review, 3, 159-172.

Ferrari, M., Quaresima, V. (2012). A brief review on the history of human functional nearinfrared spectroscopy (fNIRS) development and fields of application. Neuroimage, 63, 921-935. 
Fredrickson, J.W. (1985). Effects of decision motive and organizational performance level on strategic decision processes. Academy of Management Journal, 28 (4), 821-843.

Frydman, C., Camerer, C. (2016). Neural Evidence of Regret and its Implications for Investor Behavior. The Review of Financial Studies, 29 (11), 3108-3139.

Glueck, W.F. (1976). Business Policy, Strategy Formation, and Management Action (2nd edition). New York: McGraw Hill.

Gore, C., Murray, K., Richardson, B. (1992). Strategic decision making. London: Cassell.

Hahn, M.H., Lee, K.C., Chae, S.W. (2016). An Eye-Tracking Approach to Evaluating DecisionMakers' Cognitive Load and Need-for-Cognition in Response with Rational and Emotional Advertising Stimuli. In: C. Stephanidis (ed.), HCI 2016 - International 2016 - Posters' Extended Abstracts. Communications in Computer and Information Science, 617. Cham: Springer.

Harrison, G.W. (1994). Expected utility theory and the experiments. Empirical Economics, 19 (2), 223-253.

Hofer, C.W., Schendel, D. (1978). Strategy formulation: Analytic concepts. St. Paul, MN: West Publishing Co.

Howard, S.J., Burianová, H., Ehrich J., Kervin, L., Calleia, A., Barkus, E., Carmody, J., Humphry, S. (2015). Behavioral and fMRI evidence of the differing cognitive load of domain-specific assessments. Neuroscience, 297, 38-46.

Jaśkowski, P. (2009). Cognitive neuroscience. How brain creates mind? Warszawa: Vizja Press \& IT, (in Polish).

Kagel, J.H., Roth, A.E. (eds.) (1997). The Handbook of Experimental Economics. Princeton: Princeton University Press.

Kang, M.J., Camerer, C. (2017). Measured Anxiety Affects Choices in Experimental "Clock" Games. Research Economics (in press), Retrieved from http://www.sciencedirect.com/ science/article/pii/S1090944317300509 (24.03.2017).

Kopczewski, T., Malawski, M. (2007). Experimental Economics: Introduction and Contemporary Research. Decyzje, 8, 79-100 (in Polish).

Laureiro-Martínez, D., Venkatraman, V., Cappa, S., Zollo, M., Brusoni, S. (2015). Cognitive Neurosciences and Strategic Management: Challenges and Opportunities in Tying the Knot. In: G. Gavetti, W. Ocasio (eds.). Cognition and Strategy (pp. 351-370). Bingley: Emerald Group Publishing Limited.

Loewenstein, G., Rick, S., Cohen, J.D. (2008). Neuroeconomics. Annual Review of Psychology, 59, 647-672.

Lu, J., Zhang, G., Ruan, D., Wu, F. (2007). Multi-objective group decision making: Methods, software and applications with fuzzy set technology. London: Imperial College Press.

Mazzollini, R. (1981). How strategic decisions are made. Long Range Planning, 14 (3), 85-96. 
Mintzberg, H., Raisinghani, P., Theoret. A. (1976). The structure of 'unstructured' decision processes. Administrative Science Quarterly, 21, 246-275.

Niu, L., Lu, J., Zhang, G. (2009). Cognition-Driven Decision Support for Business Intelligence. Berlin-Heidelberg: Springer-Verlag.

Popa, L., Selejan, O., Scott, A., Mureşanu, D.F., Balea. M., Rafila, A. (2015). Reading beyond the glance: eye tracking in neurosciences. Neurological Sciences, 36, 683-688.

Purves, D., Augustine, G.J., Fitzpatrick, D., Hall. W., LaMantia, A.S., White L. (2012). Neuroscience. 5th edition. Sunderland: Sinauer.

Purves, D., Cabeza, R., Huettel, S.A., LaBar, K.S., Platt, M.L., Woldorff, M.G. (2013). Principles of Cognitive Neuroscience. Sunderland: Sinauer.

Schwenk, C.R. (1984). Cognitive simplification processes in strategic decision-making. Strategic Management Journal, 5 (2), 111-128.

Shiv, B., Bechara, A., Levin, I., Alba, J.W., Bettman, J.R., Dube, L., Isen, A., Mellers, B., Smidts, A., Grant, S.J., McGraw, P.A. (2005). Decision Neuroscience. Marketing Letters, $16(3 / 4), 375-386$.

Simon, H.A. (1960). The new science of management decision. Reprinted in: D.S. Pugh (1971) (ed.). Organization theory: Selected readings (pp. 189-218). Middlesex, England: Penguin Books.

Simon, H.A. (1977). The new science of management decision. Englewood Cliffs: PrenticeHall.

Van de Ven, A.H. (1992). Suggestions for studying strategy process: A research note. Strategic Management Journal, 13 (Winter special issue), 169-188.

Volz, K.G., von Cramon, D.Y. (2006). What Neuroscience Can Tell about Intuitive Processes in the Context of Perceptual Discovery. Journal of Cognitive Neuroscience, 18 (12), 2077 2087.

Wang, H., Coble, C., Bello, P. (2006). Cognitive-affective interactions in human decision-making: A Neurocomputational Approach. In Proceedings of the 28th Annual Meeting of the Cognitive Science Society, Vancouver, BC, Canada, 2341-2346.

Yaqub, M.Z., Saz, G., Hussain, D. (2009). A Meta Analysis of the Empirical Evidence on Expected Utility Theory. European Journal of Economics, Finance, and Administrative Sciences, 15, 117-133.

Zaleśkiewicz, T. (2008). Neuroekonomia. Decyzje, 9, 29-56.

Zander T., Horr, N.K., Bolte, A., Volz, K.G. (2016). Intuitive decision making as a gradual process: investigating semantic intuition-based and priming-based decisions with $\mathrm{fMRI}$. Brain and Behavior, 6 (1), 1-22. 